\title{
What works to improve the quality of student learning in developing countries?
}

\author{
Serena Masino ${ }^{\mathrm{a}}$, Miguel Niño-Zarazúa ${ }^{\mathrm{b}, *}$ \\ a Oxford Department of International Development (ODID), University of Oxford, United Kingdom \\ ${ }^{\mathrm{b}}$ United Nations University, World Institute for Development Economics Research (UNU-WIDER), Helsinki, Finland
}

A R T I C L E I N F O

Article history:

Available online 23 December 2015

\section{JEL classification:}

I25

I28

I38

C10

O50

\section{Keywords:}

Education quality

Student learning

Education policy

Developing countries

Systematic review

\begin{abstract}
A B S T R A C T
We conducted a systematic review to identify policy interventions that improve education quality and student learning in developing countries. Relying on a theory of change typology, we highlight three main drivers of change of education quality: (1) supply-side capability interventions that operate through the provision of physical and human resources, and learning materials; (2) policies that through incentives seek to influence behaviour and intertemporal preferences of teachers, households, and students; (3) bottom-up and top-down participatory and community management interventions, which operate through decentralisation reforms, knowledge diffusion, and increased community participation in the management of education systems. Overall, our findings suggest that interventions are more effective at improving student performance and learning when social norms and intertemporal choices are factored in the design of education policies, and when two or more drivers of change are combined. Thus, supply-side interventions alone are less effective than when complemented by community participation or incentives that shift preferences and behaviours.

( 2015 UNU-WIDER. Published by Elsevier Ltd. This is an open access article under the CC BY-NC-ND
\end{abstract} license (http://creativecommons.org/licenses/by-nc-nd/4.0/).

\section{Introduction}

Since the seminal work of Becker (1962) and Schultz (1961) on the theory of human capital, education policy has been increasingly the object of research, for its intrinsic importance but also for its instrumental value in the improvement of society. Theoretical economic models have emphasised the role of schooling in determining the returns to education that ultimately foster economic growth (Lucas, 1988; Becker et al., 1990; Rebelo, 1991; Romer, 1994). Empirical studies show that education and the policies that facilitate the process of innovation and knowledge creation have profound effects on the long-run economic growth and development patterns (Barro, 1991; Rebelo, 1991; Benhabib and Spiegel, 1994; Barro and Sala-i-Martin, 1998). The benefits of information and knowledge diffusion in facilitating economic transactions, productive arrangements, social interactions, and political participation are also widely acknowledged (Sen, 1999).

Investing in human capital through education policy has been a growing priority for developing countries since the post war era, and such efforts are often supported by foreign aid. During the

\footnotetext{
* Corresponding author.

E-mail address: miguel@wider.unu.edu (M. Niño-Zarazúa).
}

1970s and 1980s, and with many African nations achieving independence from colonial powers, much of the education aid focused on improving access to education via supply-side policies, such as the construction of schools and the provision of equipment (Coombs, 1985; Tilak, 1988). These policies were expected to lead to enhanced productivity, economic growth, and development. In addition, improving teaching abilities via training of teachers and reforming learning materials was funded as an effective way of enhancing education quality (World Bank, 1980). During that period, around $50 \%$ of all bilateral co-operation aid went to secondary education, and nearly a third to tertiary and technical education. These sectors were, in fact, regarded as catalytic for growth and development (OECD, 2012). It was not until the late 1980s that education aid and public policies began to shift towards improving access to primary education, as the latter was recognised to have the highest economic returns in developing countries (Psacharopoulos, 1981, 1985; Psacharopoulos et al., 1986; Petrakis and Stamatakis, 2002; Psacharopoulos and Patrinos, 2004; Asiedu and Nandwa, 2007). The shift was followed, in 1990, by the World Declaration on 'Education for All', adopted by the United Nations Educational Scientific and Cultural Organisation (UNESCO) and other multilaterals and more recently by the current formulation of the Millennium Development Goals (MDGs), where access to education represents a cornerstone for expanding human 
capabilities and freedoms (UNESCO, 2007). This approach has since become the dominant paradigm of education aid in the developing world (see Riddell and Niño-Zarazúa, 2016).

More recently, the education aid policy debate has gradually shifted from access to schooling to improving learning quality. The transition is likely to dominate the post-2015 global development framework for education development, and can be explained by two important factors: firstly, growing evidence emphasises that quality of education is what matters for economic development. Hanushek and Kimko (2000) and Barro (2001), for example, find that test scores are better predictors of real per capita GDP growth than years of schooling attainment. Hanushek and Woessmann (2008, 2012), Hanushek et al. (2010), Jamison et al. (2007), Laurini and Andrade (2012), and UNESCO (2011), among others, show that cognitive skills are more strongly associated with increases in earnings and development outcomes than schooling attainment.

The second factor is the recognition that poor quality of education remains endemic in developing countries. UNESCO (2014) reports that 250 million children are functionally illiterate and innumerate despite $50 \%$ of them having spent at least four years in school. Similarly, in India, more than half of all grade five students' reading ability stands at grade two level (ASER, 2015). Teacher qualifications and attendance is equally problematic with less than $75 \%$ of primary school teachers in developing countries being trained according to national standards (UNESCO, 2014). Along the same lines, Glewwe et al. (2010) report that teachers from rural schools in Kenya were absent $20 \%$ of the time; while, in Zambia and Pakistan, teachers were absent, respectively, 18 and $10 \%$ of the time (Das et al., 2004; Reimers, 1993). Other supply-side concerns such as overcrowded classrooms, lack of teaching material, and poor infrastructure are also obstacles for good learning environments. In sub-Saharan Africa, the rapid increase in school enrolment rates accompanied by low teacher recruitment means that the pupil-teacher ratios in primary education is now exceeding 40:1 (UNESCO, 2014). Demand-side factors such as discriminatory social norms, group incentive dynamics, and intertemporal choices can also influence the utilisation of education services.

Previous analytical review studies have examined the relationship between policy design and cognitive skills and learning at various levels of education, while focusing largely on supply-side interventions (Glewwe, 2002; Kremer, 2003; Glewwe and Kremer, 2006; Kremer and Holla, 2009; Glewwe et al., 2014). Recent systematic reviews have focused on a number of issues including (i) assessing the effectiveness of policies that improve enrolment in primary schools (Petrosino et al., 2012); (ii) supply-side and demand-side factors in school attendance and learning (Krishnaratne et al., 2013); (iii) school-based interventions looking exclusively at the evidence from randomised control trials (McEwan, 2014) and (iv) studies with a specific regional focus (Conn, 2014). This study contributes to the existing debate by conducting a systematic review of the literature on education policies that specifically target the quality of student learning at basic education level in developing countries. In line with this focus, we decided to consider test scores and depart from the examination of outcomes such as school enrolment and attainment, pupil-teacher ratios, drop-out rates, and repetition rates. The choice is motivated by the fact that mere indicators of enrolment and attainment do not necessarily capture the quality of the delivered education, and the level of students' achievement (UNESCO, 2014). Our study collects evidence from experimental and quasi-experimental studies, and, overall, our findings suggest that interventions are more effective at improving student performance and learning when social norms and intertemporal choices are factored in the design of education policies; and when a combination of policy approaches is adopted. We conclude that supply-side interventions are less effective alone than when complemented by community participation interventions or by incentives that shift preferences and behaviours.

The remaining of the paper is organised as follows: Section 2 presents a theory of change typology, outlining the drivers that facilitate improvements in education quality in developing countries, while Section 3 presents the systematic review methodology. Section 4 presents the synthesis of evidence, which is divided into three groups: (i) supply-side capability interventions, (ii) incentives for changing preferences and behaviours, and (iii) participatory and community management interventions. Finally, Section 5 concludes by discussing the findings and drawing some possible policy implications.

\section{Policy innovations to improve education quality and student learning: a theory of change typology}

We begin the discussion by developing a theory of change typology based on the systematic review. The theory of change involved, first, the identification of the targeted outcome, which in our case is student achievement as measured by test scores in reading, writing and mathematics. Secondly, the theory of change identified various transmission channels through which policy strategies impact education quality in developing country contexts. Typically, a variety of interlinked factors affect the desirable outcomes overtime. Therefore, it was important to disentangle the short-term from the medium and long-term objectives that also influence targeting mechanisms and the process of impact evaluation of policies.

From the systematic review analysis, we were able to identify three main drivers of change for advancing education quality and student learning in developing countries (see Fig. 1). These consist of (i) interventions aiming to enhance the supply-side capabilities of education institutions, (ii) interventions targeting supply-side and demand-side changes in preferences and behaviours that affect the utilisation of education services, and (iii) bottom-up and top-down participation and management interventions. In the following sections we discuss these drivers of change in more detail.

\subsection{Supply-side capability interventions}

Supply-side interventions aim to raise student achievements by targeting infrastructure or organisational deficiencies through, for example, improving physical infrastructure, providing teaching materials, and training and hiring extra teachers. Financial resources provided by governments and/or aid-funded programmes can take the form of directed or generalised financial allocations to improve physical conditions of existing schools (as in Paqueo and Lopez-Acevedo, 2003; Bjorkman, 2004; BarreraOsorio, 2007) or involve the construction of new schools (as in Burde and Linden, 2013). Other studies have also examined the allocation of financial resources to provide school materials such as computers, flip-charts and textbooks, which support the learning process and improve teaching quality (see for example Barrera-Osorio and Linden, 2009; Glewwe et al., 2004; Vermeersch and Kremer, 2005; Glewwe et al., 2009; Evans et al., 2009; Banerjee et al., 2007; Linden, 2008; He et al., 2008; Muralidharan and Sundararaman, 2010).

Supply-side education policies have also focused on hiring extra teachers, so as to decrease the prevailing high teacher-pupil ratios in many developing countries, and also complement permanent teachers with younger, often more motivated, temporary teachers (see e.g. Duflo et al., 2015; Asadullah, 2005; Linden, 2008; Muralidharan and Sundararaman, 2011). Finally, supply-side policies have also taken the form of management related 


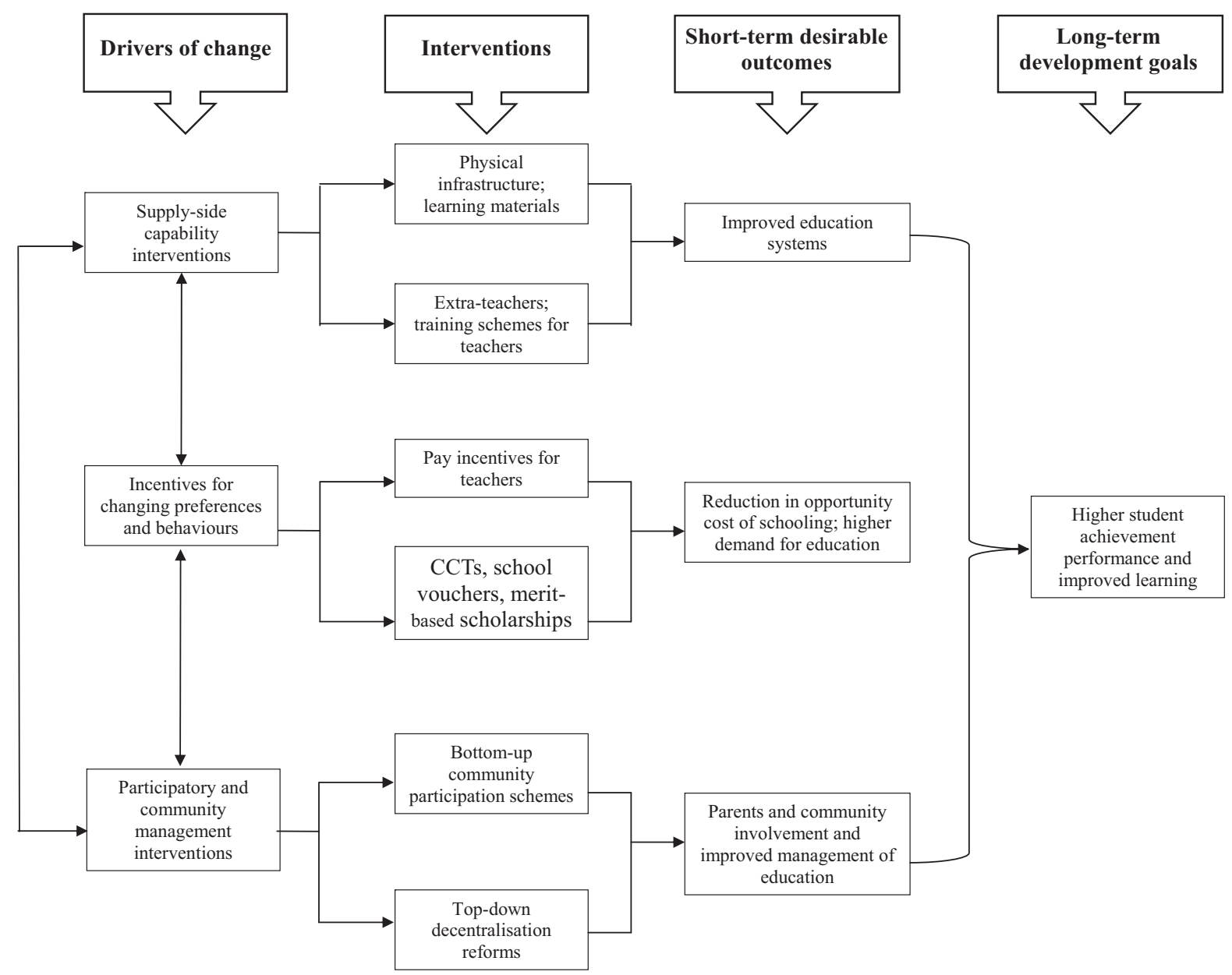

Fig. 1. Theory of change flow diagram.

interventions aiming to improve the functioning and efficacy of education systems as a whole (García Palomer and Paredes, 2010; King and Ozler, 2005; Galiani et al., 2008; Lassibille et al., 2010). This type of interventions can be seen as cross-over policy between resource-provision and participation-related drivers of change.

\subsection{Incentives for changing preferences and behaviours}

Monetary incentives have been used to produce changes in the behaviour and preferences of agents involved both in the provision and utilisation of education services, namely teachers, students and parents. Incentives for teachers aim to improve the quality of teaching whereas incentives for students and parents are concerned more with behaviours and preferences that affect the demand for, and utilisation of education services. Several studies have, in fact, shown that, in contexts where the demand for educational services is constrained by societal and economic factors, supply physical and human resources alone can often result in a waste of limited resources (Vermeersch and Kremer, 2005; Glewwe et al., 2009; Muralidharan and Sundararaman, 2010).

In this sense, teachers' commitment to attend the classroom regularly can depend on a number of factors, including the level of wages and the nature of their contracts (permanent vs. temporary), the distance to the workplace and school facilities, and the existence of systems to monitor their work shifts and attendance. In some contexts, the provision of monetary incentives can be effective to discourage absenteeism. In others, teachers may respond better to non-monetary incentives, such as monitoring and pay sanctions and other enforcement mechanisms. It has been reported, however, that such policies sometimes fail to achieve long-term improvements in students learning, by simply encouraging teachers to boost students' short-term performance, so as to meet the target to which the incentives are tied (see discussion below on the studies of Rau and Contreras, 2009; Glewwe et al., 2010; Kingdon and Teal, 2007; Duflo et al., 2012; Muralidharan and Sundararaman, 2011).

Similarly, a number of strategies have been deployed targeting the behaviours of students and their parents. Examples are the Colombian school voucher programme PACES, analysed by Angrist et al. (2002, 2006), or Chile's school voucher scheme discussed by Contreras (2001), Hsieh and Urquiola (2006), and Anand et al. (2009). These aim to facilitate enrolment and attendance of lowincome students in better quality (often private) schools. School vouchers work through two parallel mechanisms: first, they provide students with the financial resources needed to attend schools in more conducive environments. Second, they aim to influence students' intertemporal choices and influence the allocation of time to education over labour supply.

Conditional cash transfers (CCTs), and merit-based scholarships and grants are also designed to induce behavioural change towards an increased utilisation of education services (Das et al., 2004; Kremer et al., 2009; Baird et al., 2011). In those cases, the financial support is conditional upon, or tied to, student and household behaviour including school attendance, grade progression, or test score attainment. In this way, students' choices are directly 
targeted to bring about the desired change in behaviour. Girls are often given larger income support than boys to compensate for gender bias and normative discrimination (Niño-Zarazúa, 2011; Martínez Franzoni and Voorend, 2012). Low-income and vulnerable groups, including ethnic or religious minorities, are also targeted by CCTs, as these groups are exposed to higher risk factors for school dropouts (Heckman and LaFontaine, 2010; Suh and Suh, 2007). As depicted in Fig. 1, by coupling behavioural incentives with financial resources at the school level, school vouchers, CCTs, and merit-based scholarships effectively cross-over the supplyside of interventions.

\subsection{Participatory and community management interventions}

The third driver of change runs through bottom-up or top-down participatory and community management interventions. On the one hand, bottom-up policies diffuse and disseminate relevant information among actors, to raise awareness of community needs for quality education services and of possible solutions. Often such initiatives, in combination with incentives to change preferences and behaviours, seek to alter discriminatory social norms that restrict demand for education services, particularly among girls and vulnerable groups. Some examples of bottom-up interventions have been studied in Jimenez and Sawada (1999) and Di Gropello and Marshall (2005).

On the other hand, top-down interventions channel or optimise resource deployment through management reforms and standards of practice enforcement. These interventions are often complemented by the provision of resources, while the community participatory component serves to rationalise the service flow of the education system. Examples of such interventions are discussed in King and Ozler (2005), Galiani et al. (2008), García Palomer and Paredes (2010), and Lassibille et al. (2010). Participatory community management interventions can thus be seen as an important complement to both supply and demand-side drivers of change, insofar as they generate conducive environments for social change.

\section{Methodology}

We conducted a systematic review of the literature on the quality of student learning, following the Cochrane Handbook for Systematic Reviews of Interventions (Higgins and Green, 2008) and the PRISMA guidelines (Moher et al., 2009). The review is based on the largest relevant databases available, including Econlit, Social Science Citation Index, JSTOR, SCOPUS, Eldis, 3ie database, J-PAL Library, and Google Scholar.

Search criteria included academic articles adopting a rigorous quantitative impact evaluation design, that assessed the effectiveness of policies targeting the improvement of education quality in pre-school, primary, and secondary education, and which were published in English. The search was restricted from 1990 onwards. This is due, firstly, to a limited number of experimental or quasiexperimental studies conducted before 1990 . Secondly, 1990 is the year when the World Declaration on Education for All was adopted by UNESCO. The Declaration sparked considerable expansion in research, as well as in funding and innovation of the education aid architecture; this then paved way to the introduction of the MDGs in 2000. In order to diminish the risk of publication bias, we included unpublished studies (grey literature), such as working papers. Non-academic policy documents such as policy briefs and reports that lack rigorous methodology were excluded from the review.

The search protocol was complemented with a hand search of reference lists of previous review studies to identify additional relevant material. The initial search was repeated at a later stage, in
February 2013, to update the review. To make the searching process more efficient, we combined a number of study 'identifiers' that included (i) research design (e.g. RCTs, randomised experiment, randomised controlled trial, quasi-experimental method, difference-in-differences, regression discontinuity design, matching methods, instrumental variables, structural equation modelling), (ii) type of intervention (e.g. improved school infrastructure, allocation of extra teachers, school meals, school fees, textbooks, school vouchers, conditional cash transfers), (iii) outcomes (e.g. reading, mathematics, and writing test scores), (iv) education level, which was limited to primary and secondary education, and (v) the context of intervention (e.g. rural vs. urban settings, developing countries, Africa, Asia, Latin America, Middle East). Group identifiers were combined with the Boolean operator 'AND', while they were connected with the Boolean operator 'OR'.

We selected 220 studies for screening on the basis of their abstracts and keywords, out of 17,800 search hits of related studies. Of the 220 studies, 146 were excluded due to methodological limitations, leaving 74 studies that were fully scrutinised on the basis of their content; of these, 36 did not meet the eligibility criteria in terms of outcomes, research design, or coverage. Finally, in total, 38 studies were included for analysis in the systematic review (see Fig. 2).

As the primary objective of this study is to review education policies that improve the quality of learning of basic education students in developing countries, we only included studies that focused on student achievement test scores as impact outcomes. As previously mentioned, we excluded other outcomes, such as school enrolment and attainment, pupil-teacher ratios, drop-out rates and repetition rates. This is due to the fact that test scores in subjects such as mathematics and language are better proxies for learning performance and achievement, while enrolment or

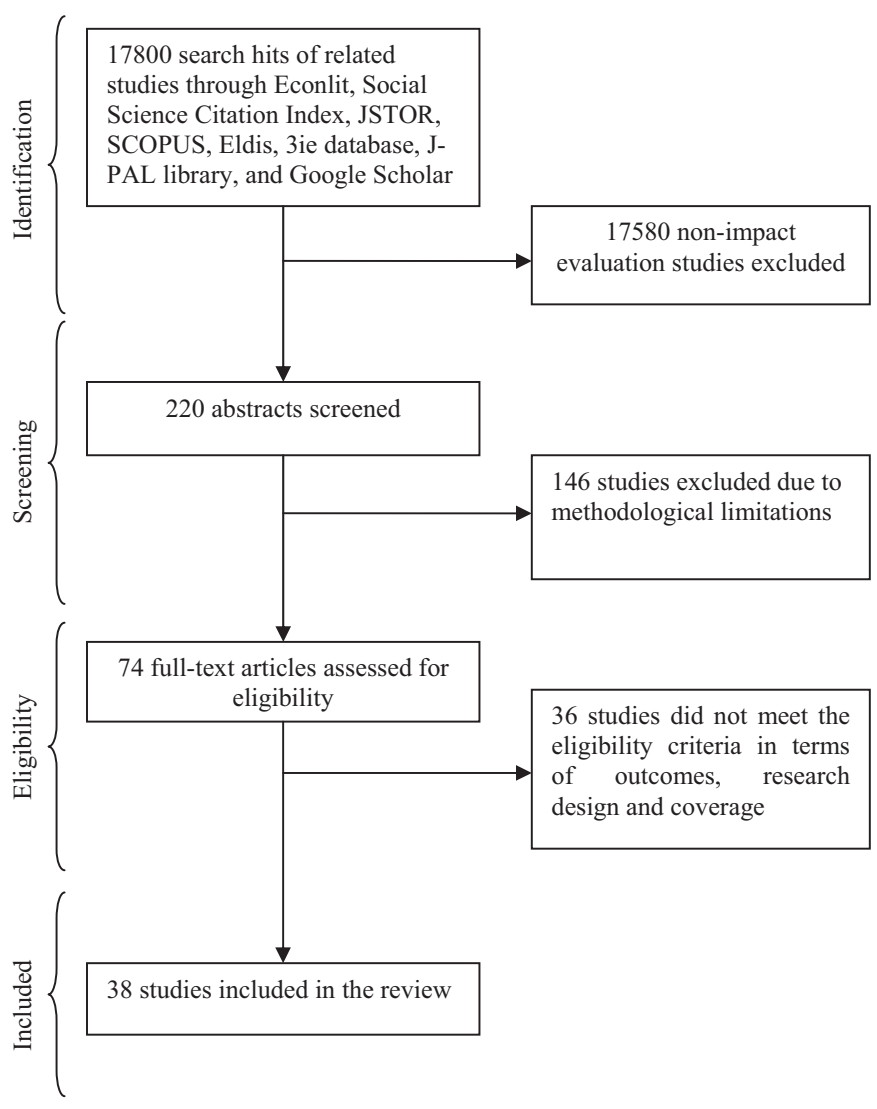

Fig. 2. Systematic review flow diagram. 
attainment levels do not necessarily give a measure of education quality. Test scores can be either administered by official institutions that oversee students' grade progression, or during pre- and post-implementation phases of policies that are analysed by researchers in the context of independent evaluations.

It is important to point out that there are a number of issues regarding the comparability of student test scores across contexts, learning subjects, and grades. For instance, student achievement test scores for primary school levels do not reflect the same cognitive progression of secondary school levels. Comparing the two or pooling them together in the same analysis would yield misleading conclusions. In addition, internationally comparable test scores are available for a relative small number of industrialised and middle income countries, ${ }^{1}$ but these are not strictly comparable with most student achievement test scores available in developing countries. The standardisation of measures, via standard deviations (SD), can nevertheless help us compare the effectiveness of policies across different types of contexts. Following a programme or intervention, the standard deviation indicates the amount of variation the latter produced in student learning, compared to changes in learning observed in a control group. A 0.2 SD change in test scores would amount to a child moving from the 50th to the 58th percentile of her/his group test score distribution. In the education literature, an increase of less than $0.1 \mathrm{SD}$ is typically considered to be a small effect, while an increase of more than $0.3 \mathrm{SD}$ is considered a large effect. An increase of more than $0.5 \mathrm{SD}$ is regarded as a very large effect (Dhaliwal et al., 2012).

Therefore, this study only includes experimental or quasiexperimental studies that use standard deviations of student achievement test scores to measure policy impact. As explained, this is done to render cross-country comparisons of policy impact more meaningful; it does not, however, undermine the relevance of other studies that have adopted qualitative methods of research enquiry. The study also adopts a geographical inclusion criterion by focusing on studies conducted in countries defined as low or middle-income by the World Bank's Atlas classification system, which is based on gross national income (GNI) per capita. $^{2}$

Out of the 38 selected studies, 23 adopted experimental designs, while the remaining 15 followed quasi-experimental methods. The large number of recent studies included in the review reflects the increasing interest in issues related to education quality among the research community. With regard to the geographical coverage, the review included studies conducted in 15 countries located in three major geographical regions: Central Asia (Afghanistan) and South-Asia (Bangladesh, India); Latin America (Argentina, Chile, Colombia, El Salvador, Honduras, Mexico, Nicaragua), and sub-Saharan Africa (Kenya, Madagascar, Malawi, Uganda, Zambia). No studies conducted in Middle Eastern or North-African countries were identified, while some studies in Central or East Asia did not meet the inclusion criteria.

\section{Synthesis of evidence}

In this section, we discuss the synthesis of evidence, following the policy classification outlined in the theory of change presented in Section 2. To summarise: the first group of policies aims to

\footnotetext{
${ }^{1}$ For example, the Programme for International Student Assessment (PISA).

2 Based on 2011 data on GNI per capita, developing countries were classified as follows: low income countries were those with annual GNI per capita of US\$1025 or less; lower middle income countries were those with GNI per capita between $\$ 1026$ and \$4035; and upper middle income countries where those with GNI per capita in the rage of $\$ 4036-12,475$. For more information, see http://data.worldbank.org/ about/country-classifications.
}

improve education quality through the strengthening of supplyside capabilities of education systems via, for example, the provision of computers and extra-teachers. The second group of policies aims to influence individual preferences and behaviours via the provision of incentives. This group of policies is further divided into (i) supply-side incentives (e.g. payment incentive schemes for teachers); (ii) demand-side incentives (e.g. meritbased scholarship programmes), and (iii) supply-side plus demand-side incentives (e.g. school voucher programmes and CCTs). A third group of policies relies on participatory and community interventions with the objective of improving the management of education systems. Examples of these policies are country-wide school decentralisation reforms and community involvement programmes. A synthesis of evidence is presented in Table A1 in Appendix A.

\subsection{Supply-side capability interventions}

A number of studies examine policies that provided additional resources for schools and teachers, in an attempt to improve education quality and student learning. Changes in outcomes varied across contexts, but overall, the analysis suggests that it is not sufficient to limit policy strategies to the provision of supplyside capabilities. For instance, Asadullah (2005) reports that in Bangladesh secondary school achievement test scores were not improved after reductions in class-size. The author attributed the result to the lack of complementary learning materials and teaching improvements. This is in line with what the findings of the study by Jones (2016) in this Issue also indicates. Similarly, Muralidharan and Sundararaman (2010) found that, in India, teacher-aid tools, such as exam performance diagnostics, began to produce positive effects only after they were complemented with payment incentives tied to student achievement.

It appears that demand-side factors often undermine the effectiveness of supply-side capability interventions. This was particularly evident for policies that exclusively provided school materials. In fact, some of these policies resulted in exclusion errors, typically of the weakest students. For example, the Mexican compensatory programme (PARE) analysed in Paqueo and LopezAcevedo (2003) aimed to improve access to, and quality of, schools in the four poorest Mexican states, by providing financial resources. But the adopted top-down targeting mechanism failed to reach the poorest students. Similarly, the textbook distribution intervention analysed in Glewwe et al. (2009) only increased the performance of the strongest and often better-off students, while poorer students were unable to properly understand books written in English. Other interventions failed to produce significant gains in student learning because key complementary resources were needed before inputs such as flip-charts could result in significant learning improvement (Glewwe et al., 2004).

Nevertheless, a group of supply-side capability interventions did succeed in raising student achievement test scores. For example, the PACE-A programme analysed in Burde and Linden (2013), which involved the construction of village-based community schools in rural north-western Afghanistan, produced a very sizable effect on both boys' and girls' school test scores. The main channel through which the programme had an impact was the reduced transaction costs in terms of distance and travelling time pupils had to spend to attend traditional public schools, which are usually located further away from rural communities. Additional positive evidence from supply-side interventions came from Kenya, where school meals and school uniforms improved students' performance (Vermeersch and Kremer, 2005; Evans et al., 2009). Vermeersch and Kremer (2005) specify, however, that the gains were mainly due to an induced increased attendance, rather than the result of improvements in cognitive abilities through nutritional intake. 
Also, in Kenya, Duflo et al. (2015) found that additional noncivil-service contract teachers hired by parent-teacher associations increased test scores only for those students that were assigned to the new teachers, which seems to be explained by contract teachers often using more effort than permanent teachers, in order to get promoted to receive a permanent contract. For the students assigned to regular pre-existing teachers, the reduced class size resulting from the hiring of extra teachers did not translate in any sizable positive effect on performance. This is consistent with the evidence reported in Asadullah (2005) and Jones (2016) in this Issue.

A number of recent studies have examined whether teaching quality could be enhanced through compensatory or 'remedial' education schemes, or through new teaching methods such as flashcards and computer assisted learning. The outcomes of such programmes are generally positive, with gains in both maths and language test scores. Something that emerged in more than one study is that, when interventions substitute teachers' inputs, their efficacy was lower than when they complemented them (Linden, 2008; He et al., 2009). For example, the study by Muralidharan and Sundararaman (2011) found that, although providing extra schooling materials helped improve student performance, supplying additional contract teachers was a more effective policy to improve the quality of learning. Furthermore, the effectiveness of remedial education schemes was found to be largely driven by the lowest performing pupils who seemed to have benefited the most from the programmes (Banerjee et al., 2007; He et al., 2008). On the contrary, selfpaced computer assisted learning programmes, like the one analysed in He et al. (2008), were found to help stronger students the most.

\subsection{Incentive for changing preferences and behaviours}

We find that, contrary to supply-side capability interventions, incentive policies targeting preferences and behaviours have been extensively implemented at secondary school levels. This seems to reflect programme design features intended to induce shifts in individual and household behaviour and preferences, particularly at the time when the opportunity cost of schooling for low income households begins to increase. Incentive policies have focused on supply-side constraints of education systems and/or demand-side constraints.

\subsubsection{Supply-side incentives}

Pay incentives for teachers have been implemented with the aim of improving teacher attendance and performance. Results are mixed: in Chile, pay-incentive tournaments were introduced in secondary schools. The scheme provided monetary incentives to teachers who improved the performance of secondary school students over the course of a year. However, the gains in test scores were only short-lived and likely to be the outcome of teachers' opportunistic behaviour, whose actions were primarily motived by the goal of succeeding in the tournament, and not achieving longterm content-based improvements (Rau and Contreras, 2009). Similar evidence has emerged from a teacher pay-incentive programme introduced in Kenyan primary schools. As in the Chilean case, it was found that the gains in test scores were the result of teachers' short-term opportunistic behaviour to secure the pay reward (Glewwe et al., 2010).

Other similar interventions reported more positive results but only after they had been combined with monitoring and enforcement devices. In India, for example, Duflo et al. (2012) found positive test score effects, which were the result of both payincentives and increased monitoring on teachers' attendance. Also in India, Kingdon and Teal (2007) found that pay incentives raised student achievement test scores only in private schools. The results appeared to be associated with the nature of contractual arrangements of Indian public schools, where teachers enjoy, unlike in private schools, permanent contracts that diminish the potential effect of pay incentives. Muralidharan and Sundararaman (2011) also found that both individual and group pay incentives raised test scores, although individual incentives were more effective, with spillovers effects having an impact on test scores in non-incentive subjects. This indicates that complementary policies, such as attendance monitoring and sanction enforcement, together with case-specific contractual provisions, may influence the effectiveness of pay incentives to improve education quality and learning.

\subsubsection{Demand-side incentives}

Demand-side behavioural incentives have been found to achieve positive impacts on school learning in sub-Saharan African countries, although with some caveats. A Kenyan meritbased scholarship programme, which awarded primary school girls with funds to progress to secondary education, was not only effective in improving student performance but also generated positive spillover effects among boys (Kremer et al., 2009). Other studies have revealed specific factors that enhance or limit the effectiveness of such policies. For example, Nguyen (2008) found that a cost effective way to increase test scores in Madagascar was to provide students and their parents with statistics on returns to investment in education. Provision of role models was, however, only effective at improving poor students' performance when the role model was herself from a poor background. Das et al. (2004) found, in Zambia, that test score gains were only produced by cash transfers which were not anticipated by households. The result was associated with the fact that anticipated grants generated resource substitution and redistribution effects, which meant that a share of the resources were taken away from students who obtained the grant and were re-allocated for other intra-household purposes. Related to this finding, the study conducted by Baird et al. (2011) among secondary school girls in Malawi found that conditional cash transfers were more effective than unconditional cash transfers in improving student achievement test scores. The results stressed the role of conditionalities in influencing household inter-temporal preferences and decisions that affected the utilisation of education services.

\subsubsection{Supply-side plus demand-side incentives}

We also identified policies that combine supply-side capability interventions with behavioural incentives. Examples of this type of policies are vouchers programmes, which have been extensively implemented in Latin America. These programmes offer, on the one hand, monetary incentives for poor students to attend private schools that often have better records of teaching performance, and on the other hand, provide schools with the necessary resources to cover the increased demand for education services.

Angrist et al. (2002) and Angrist et al. (2006) report positive impacts of the Colombian school voucher programme (PACES) implemented in secondary schools. The renewal of grants is conditional upon satisfactory students' performance. Evidence suggests that the programme raised test scores both in the short term (Angrist et al., 2002) and in the longer term (Angrist et al., 2006; Barrera-Osorio, 2007). In Chile, a similar voucher programme was analysed by Contreras (2001), Hsieh and Urquiola (2006) and Anand et al. (2009). The evidence, in this case was inconclusive: while Contreras (2001) finds a positive impact, Hsieh and Urquiola (2006) report a decrease in test scores. Following the decision of some Chilean private schools to charge a fee on top of the government voucher, Anand et al. (2009) analysed the test 
score impact of granting low-income students scholarships to attend those schools. They found that, while students who were awarded scholarships performed better than the ones in public schools, no difference existed between the performance of scholarship-funded students and that of students attending free private voucher schools.

The study carried out in Mexico by Behrman et al. (2015) implemented a three component intervention, where pay incentives were given to students only, to teachers only, or to both and also to schools' administrative staff. The first two treatments rewarded individual performance whereas the third was designed to elicit collaboration through group performance. The policy was designed to impact multiple levels of the education system. While incentives to students only were marginally effective in improving student learning achievements, the intervention suffered from extensive cheating on the part of students. The teacher-only pay incentives were, instead, mostly ineffective. The biggest impact was, however, that of the combined incentive scheme which rewarded not only individual performance but also increased performance of groups. The authors report cheating-adjusted estimates to account for bias, but what the study highlights is the importance of carefully assessing the dynamics of such behavioural patterns when examining performance-related reward schemes.

\subsection{Participatory and community management interventions}

Participatory and community management interventions involve bottom-up and top-down policies which, by diffusing knowledge among local communities, parent-teacher associations, and parent committees, raise awareness, and increase participation and involvement in the management of education systems. Examples of bottom-up policy strategies are the EDUCO community involvement scheme in El Salvador, analysed in Jimenez and Sawada (1999), and the PROHECO participation initiative in Honduras, analysed in Di Gropello and Marshall (2005). Both interventions resulted in improved student achievement test scores.

Top-down approaches are more commonly implemented by government education agencies to improve the management and operational inefficiencies of education systems. Examples of these policies are the Nicaraguan and Argentinian decentralisation reforms, analysed in King and Ozler (2005) and Galiani et al. (2008) respectively. Other examples are the multi-level decentralisation programme in Madagascar analysed, in Lassibille et al. (2010), and the Chilean programme that transferred low-income students to schools reporting best management standards of practice (García Palomer and Paredes, 2010). These studies report mixed results: while García Palomer and Paredes (2010) found positive test score gains for students allocated to better managed schools, Galiani et al. (2008) found that test score gains resulting from the Argentinian decentralisation reform failed to reach the poorest students (Galiani et al., 2008). Autonomy in decision making at school level, following the decentralisation reform in
Nicaragua, could not explain the increases in test scores either, just the de facto existence of autonomous management practices (King and Ozler, 2005). Similarly, the study by Lassibille et al. (2010), in Madagascar, did not find any significant impact of decentralisation on exam scores.

\section{Conclusions}

This study has reviewed the available evidence on education policy to identify what works to improve the quality of student learning in developing countries. The review has focused on experimental and quasi-experimental studies of policies that were funded by national governments alone and/or with the support of donors. We have identified three drivers of change that improve, under certain conditions, student achievement performance and learning. The first driver of change is related to supply-side elements of education systems, through the provision of additional material and human resources. The second driver of change is associated with supply-side and demand-side factors that influence behaviours, and intertemporal choices of teachers, students, and households. The third driver of change is channelled through bottom-up and top-down participatory and community management strategies, via decentralisation reforms, and with the involvement of communities in the school system management.

The evidence reviewed suggests that interventions are more successful when two or more drivers of change are combined. Often, the mere provision of physical and human resources is ineffective at improving education quality, as unattended demandrelated factors can undermine the full utilisation of education services. Therefore, intertemporal choices and discriminatory social norms need to be factored in when designing education policies. Whenever demand for education is generated via community involvement or behavioural incentive programmes, the review of the available evidence suggests that it is crucial to upgrade simultaneously both infrastructure and administrative capabilities of education systems, in order to accommodate the increased demand for education without undermining quality. The growing literature on education policy based on experimental and quasi-experimental methods has helped us to better understand the underlying mechanisms at play in effective policy implementation. However, more work is still needed to examine the full costs and social benefits of these interventions, and assess the long term impacts of various types of education policies. This will require extending the focus of analysis beyond experimental and quasiexperimental research designs, to provide a more informed discussion for future education policy strategies in developing countries.

\section{Appendix A}

See Table A1. 


\begin{tabular}{|c|c|c|c|c|c|c|}
\hline Study & Setting & Funding & Study design & Study size & Intervention & Policy outcome \\
\hline \multicolumn{7}{|c|}{ Supply-side capability interventions } \\
\hline $\begin{array}{l}\text { Paqueo and Lopez-Acevedo } \\
\text { (2003) }\end{array}$ & $\begin{array}{l}\text { Mexico (urban and rural); } \\
\text { Primary (grade 6) }\end{array}$ & Government & RCT & $\begin{array}{l}897 \\
\text { (indigenous) } \\
1024 \text { (rural) } \\
1480 \text { (urban) } \\
1921 \text { (pooled } \\
\text { rural- } \\
\text { indigenous) }\end{array}$ & $\begin{array}{l}\text { Supply-side education } \\
\text { programme (PARE) aiming to } \\
\text { reduce inequality and improve } \\
\text { quality of primary education in } \\
4 \text { poorest Mexican states }\end{array}$ & $\begin{array}{l}\text { (a) Rural sector: test scores in Spanish } \\
\text { improved for all, but more so for less poor } \\
\text { students. When pooling indigenous and rural } \\
\text { samples, poorest students' scores increase by } \\
\text { only half that of less poor students overall } \\
\text { (b) Urban sector: inconclusive results due to } \\
\text { experimental implementation problems }\end{array}$ \\
\hline Barrera-Osorio (2007) & $\begin{array}{l}\text { Colombia (urban); } \\
\text { Secondary (grade 10) }\end{array}$ & $\begin{array}{l}\text { Foreign Aid and } \\
\text { Government }\end{array}$ & $\begin{array}{l}\text { Quasi- } \\
\text { experimental }\end{array}$ & & $\begin{array}{l}\text { analysis(propensity score } \\
\text { matching) }\end{array}$ & 37,300 \\
\hline $\begin{array}{l}\text { ‘Concession Schools’ } \\
\text { programme (publicly } \\
\text { subsidised private schools) }\end{array}$ & $\begin{array}{l}\text { Maths and reading scores } \\
\text { increased by } 2.4 \% \text { and } 4 \% \\
\text { respectively }\end{array}$ & & & & & \\
\hline $\begin{array}{l}\text { Barrera-Osorio and Linden } \\
\text { (2009) }\end{array}$ & $\begin{array}{l}\text { Colombia (urban); Primary } \\
\text { and Secondary (grade 3-9) }\end{array}$ & Government & RCT & 5201 & $\begin{array}{l}\text { Integration of computers into } \\
\text { language teaching in public } \\
\text { schools }\end{array}$ & $\begin{array}{l}\text { Small average treatment effect of about } 0.11 \mathrm{SD} \\
\text { About a third of the students only used } \\
\text { computers for IT training rather than } \\
\text { incorporating its use into routine language and } \\
\text { maths classes }\end{array}$ \\
\hline Bjorkman (2004) & $\begin{array}{l}\text { Uganda (nation-wide); } \\
\text { Primary (grade 7) }\end{array}$ & Government & $\begin{array}{l}\text { Quasi } \\
\text { experimental } \\
\text { analysis (D-i-D) }\end{array}$ & 96 (districts) & $\begin{array}{l}\text { Government funded per- } \\
\text { student capitation grant }\end{array}$ & $\begin{array}{l}\text { Test scores in treatment district which had } \\
\text { more exposure to grant were } 0.42 \text { SD higher }\end{array}$ \\
\hline Glewwe et al. (2004) & $\begin{array}{l}\text { Kenya (urban and rural); } \\
\text { Primary (grade 6-8) }\end{array}$ & Foreign Aid & RCT & 141,698 & $\begin{array}{l}\text { Flip-chart provision in primary } \\
\text { schools }\end{array}$ & $\begin{array}{l}\text { Flip chart provision did not result in any } \\
\text { significant increase in test scores }\end{array}$ \\
\hline $\begin{array}{l}\text { Vermeersch and Kremer } \\
\text { (2005) }\end{array}$ & Kenya (rural); Pre-Primary & Foreign Aid & RCT & $1326-1350$ & $\begin{array}{l}\text { Subsidised school meals } \\
\text { provision }\end{array}$ & $\begin{array}{l}\text { Test scores increased by } 0.40 \text { SD only in schools } \\
\text { with better trained teachers. No effect on } \\
\text { cognitive abilities, suggesting gains not a } \\
\text { nutritional effect but increased attendance } \\
\text { incentives explain score gains }\end{array}$ \\
\hline Glewwe et al. (2009) & $\begin{array}{l}\text { Kenya (rural); Primary } \\
\text { (grade 3-8) }\end{array}$ & Foreign Aid & RCT & $7354-12,663$ & Textbook provision & $\begin{array}{l}\text { Textbooks did not increase average scores but } \\
\text { only test scores of the strongest students. } \\
\text { Weaker students could not read the books as } \\
\text { English is most often their third language }\end{array}$ \\
\hline Evans et al. (2009) & $\begin{array}{l}\text { Kenya (rural); Primary } \\
\text { (grade } 1-4 \text { ) }\end{array}$ & Foreign Aid & RCT & 582 & School uniforms provision & $\begin{array}{l}\text { Students' test scores increase on average by } \\
0.25 \mathrm{SD}\end{array}$ \\
\hline Duflo et al. (2015) & $\begin{array}{l}\text { Kenya (rural); Primary } \\
\text { (grade 1) }\end{array}$ & Foreign Aid & RCT & 6531 & $\begin{array}{l}\text { Extra contract teacher hired by } \\
\text { parent-teacher associations } \\
\text { (and reduced class size) }\end{array}$ & $\begin{array}{l}\text { Test scores only increased for children assigned } \\
\text { to new contract teacher. For the remaining } \\
\text { children in consequently reduced (by half) } \\
\text { classes, no gains take place }\end{array}$ \\
\hline Burde and Linden (2013) & $\begin{array}{l}\text { Afghanistan (rural); } \\
\text { Primary (grade } 1-8 \text { ) }\end{array}$ & Foreign Aid & $\begin{array}{l}\text { RCT, } \\
\text { complemented } \\
\text { by IVs } \\
\text { estimation }\end{array}$ & 1374 & $\begin{array}{l}\text { Effect of village-based } \\
\text { community-schools provision } \\
\text { on test scores and (indirectly) } \\
\text { effect of reducing distance to } \\
\text { school on test scores }\end{array}$ & $\begin{array}{l}\text { Attending village-based schools raises test } \\
\text { scores by } 0.51 \text { SD overall (with stronger impact } \\
\text { on girls and on children who would not attend } \\
\text { village-based schools without treatment). } \\
\text { Reducing school distance by } 1 \text { mile improves } \\
\text { scores by } 0.15 \mathrm{SD} \text { (boys) to } 0.24 \mathrm{SD} \text { (girls). }\end{array}$ \\
\hline Asadullah (2005) & $\begin{array}{l}\text { Bangladesh (nation-wide) } \\
\text { Secondary (grade 11) }\end{array}$ & Government & $\begin{array}{l}\text { Quasi- } \\
\text { experimental }\end{array}$ & & $\begin{array}{l}\text { analysis(regression } \\
\text { discontinuity design) }\end{array}$ & 2165 \\
\hline Effect of class size reduction & Smaller class size does not & & & & & \\
\hline
\end{tabular}

ores in Spanish dor all, but more so for less poor (n) ents overall

Small average treatment effect of about $0.11 \mathrm{SD}$ third of the students only used corporating its use into routine language and

and teacher quality 
Incentives for changing preferences and behaviours

\section{Angrist et al. (2002)}

Secondary (grade 6-8)

Angrist et al. (2006)

Contreras (2001)

Hsieh and Urquiola (2006)
Colombia (nation-wide); Secondary (grade 10)

Chile (nation-wide); Secondary (grade 10)

Chile (nation-wide); Primary and Secondary (grade 4 and 8 )
Foreign Aid and

Government

RCT

(a) Remedial education in basic literacy and numeracy skills (b) Computer assisted learning targeting maths skills

Computer assisted learning, as substitute (in school

experiment) or complement for teacher (out of school experiment)

New teaching methods (PicTalk computer machine and flashcard games) to improve teaching of foreign languag (English)

Literacy skills schoo programme (three types: in school, out of school, and preschool)

Provision of low cost diagnostic teachers

(language)

$12,255-14,797$

(maths)

$12,410-14,963$

(language)

Provision of an extra contract teacher and extra schooling materials

282

Foreign Aid and

bounds)

Quasi-

Government

experimenta analysis (two stage leas

squares)

Government Cross-sectional and IV analysis

PACES vouchers funding low income students' private secondary education (grant renewal conditional on students' performance) PACES vouchers funding low income students' private education (grant renewal
conditional on performance)

56,200 (male) 62,900 (female)

School Voucher System (publicly subsidised private schools)

Government voucher scheme allowing any student wishing feedback to teachers on students' performance

(a) Average test scores increased by $0.28 \mathrm{SD}$, result driven by lowest performing children (b) Maths test scores increased by $0.47 \mathrm{SD}$

CAL lowered maths scores by $0.57 \mathrm{SD}$ when implemented as a substitute for teachers, but improved them by $0.28 \mathrm{SD}$ when used as a complement (the result is driven by weaker students, whose scores increase by $0.40 \mathrm{SD}$ ) Scores are raised by $0.25-0.35$ SD by both games and computer-assisted learning. When students' own teachers delivered the interventions, positive spillover raised maths scores too and weaker students benefited the most. Stronger students benefited more from the self-paced computer assisted learning method

Pre-school and out of school interventions generated higher gains $(0.55 \mathrm{SD}$ and $0.70 \mathrm{SD}$, respectively) compared to the in-school setting. Highest gains where for ex-ante lowest performing students

A supply-side intervention to provide feedback diagnostic was not enough to generate teache incentives to improve students' exam scores (companion paper shows that coupled with pay incentives diagnostic feedback provides valuable input)

Test scores increased by $0.15 \mathrm{SD}$ in maths and $0.13 \mathrm{SD}$ in language. Intervention is particularly beneficial for students in 1 st school year and in remote schools

Provision of extra resources raised test scores by $0.10 \mathrm{SD}$ on average, which is $0.13 \mathrm{SD}$ lowers by 0.10 DD on average, wich is 0.13 SD lower by the pay incentive scheme to do so to move from a public to a private school
The reform did not translate in positive

decreased. The only tangible result has been middle class exodus from public schools 


\begin{tabular}{l} 
Study \\
\hline Anand et al. (2009) \\
Scholarship provision to low \\
income students attending \\
private voucher school which \\
charge fees on top of the \\
voucher
\end{tabular}

voucher

Rau and Contreras (2009)

Teacher pay incentives to raise test scores (assessment of tournament competition vs. 'gift-exchange' effect)

Behrman et al. (2015)

Das et al. (2004)

Nguyen (2008)

Kremer et al. (2009)

Glewwe et al. (2010)

Baird et al. (2011)

Setting

Chile (urban); Primary

grade 4)

Funding

Government

Study design

Study size

Quasi-

Low income students

attending fee-charging

private schools thanks to a

scholarship score $0.20 \mathrm{SD}$

higher than those attending

public schools, but score no

higher than low income

students attending free

private voucher schools

Chile (nation-wide):

Primary and Secondary

(grade 4, 8, 10)

Competing in a tournament

for pay incentive

for pay incentive
assignment raised test

scores. But after winning,

teachers do not act upon

teachers do not act upon
reception of the bonus in

way that maintains the

score gains (e.g. out of

gratitude)

Mexico (nation-wide,

mostly rural); Upper

Secondary (grade 10-12)

Government

RCT

Quasi-

experimental

nalysis(regression

discontinuity design and D-i-D

955-1740

matching)

$11,300-17,800$

ALI: Individual student and teacher pay incentive schemes:

and combined incentive

scheme to students, teachers

and school administrative staff

for both individual and group

performance improvement.

Natural

Zambia (urban and rural):

Government

Primary (grade 5-6)

Madagascar (rural);

Primary (grade 4)

Foreign Aid and

Government

experime

and IV analysis

164 (schools)

Anticipated vs. unanticipate

cash transfers for school

attendance

Provision of statistic

information on education

earning returns and/or role models

Kenya (rural); Primary

Foreign Aid

RCT

1153-3602

(pooled

768-2106

(Busia)

(Busia)

(Teso)

15,641

Kenya (rural); Primary $\quad$ Foreign Aid

RCT

Malawi (urban and rural):

Secondary (grade 5-8)
Foreign Aid

RCT
Merit based scholarship award to fund secondary school

progression for girls

Teacher pay incentive scheme tied to students' performance in exams

Conditional vs. Unconditional Cash Transfer Schemes
Teacher incentive pay scheme were not effective on their own, while student pay incentive scheme were (0.2-0.3 SD gain). The biggest impact was, however, that of the combined incentive scheme which rewarded not only individual performance but also increased performance of groups (0.3-0.6 SD gain). Estimates are adjusted as cheating proved to be substantial.

Maths and language test scores increase more when cash transfers are unanticipated by households. This is because anticipated grants lead to substitution effect of resources

Providing statistics raises scores by $0.20 \mathrm{SD}$ on average, with an impact as high as $0.37 \mathrm{SD}$ for students underestimating returns prior to RCT Role models only increased scores when of lowincome background (0.17 SD); with a higher impact on poorer students (0.27 SD)

Girls' test score increased by between 0.20 and $0.30 \mathrm{SD}$ in Busia district. There is inconclusive evidence with regards to Teso. The impact also had spillover effects on boys' score increases and on test scores of girls who were not awarded the scholarship.

Test scores increased ad-hoc to achieve pay rise (ability to answer MCQs and filling the gaps questions). Thus, only test taking skills

improved but no impact on content learnin Test scores are 0.14 SD higher in English, $0.12 \mathrm{SD}$ higher in maths and $0.17 \mathrm{SD}$ higher in overall cognitive abilities for girls who received the conditional cash transfer 
Teacher pay incentive in private and quasi-

experimental

analysis (IV)

Duflo et al. (2012)

Muralidharan and

Sundararaman (2011)
India (rural); Informal learning centres (primary)

India (rural); Primary

(grade 1-5)
Foreign Aid
Foreign Aid

García Palomer and Paredes (2010)

Low income students'

attendance of private

subsidised SIP schools which implement best practice and management standards

Di Gropello and Marshall

2005)

$$
\text { (grade 4) }
$$

Chile (urban): Primary

Maths test scores increas by about 32 points in SIP schools as a result of goo management practices

Honduras (rural); Primary grade 3)

King and Ozler (2005)

Galiani et al. (2008)

Lassibille et al. (2010)
Nicaragua (nation-wide); Primary and Secondary (grade 4 and 10)

Argentina (nation-wide); Secondary (grade 10)

Madagascar (urban and rural); Primary (grade 3-5)
Government
RCT
1760-1893

$12,255-14,797$

(maths)

$12,410-14,963$

(language)

605

Quasi-

experimenta

analysis

(structura

equation

modelling and

V)

Teacher pay incentive and monitoring scheme to reduce absenteeism

Individual teacher pay

incentive scheme and group

teacher pay incentive scheme (school-level)

EDUCO's Community

Involvement and

Decentralisation Programme

analysis(propensity score matching and structura equation modelling)

Community school participation programme (PROHECO)

experimenta

analysis

(structural

equation

model)

and IV Analysis

945 (primary)

911(secondary)

Decentralisation of school-

management reform

Quasi-

experimental

analysis (D-i-D)

RCT

3273

22,000

Decentralisation of secondary school system

Improvement of school management practices at various levels of decentralisation
A 22\% increase in test scores follows an increase in teacher pay from $1 \mathrm{SD}$ below to $1 \mathrm{SD}$ above the mean. This is only found in private schools, as a result of increased teacher effort (as public school contracts are mostly permanent in India, pay incentives do not generate effort increases in that context)

A year after the intervention test scores were 0.17 SD higher. Gains are the results of both incentives and increased monitoring

The individual incentive scheme improved test scores by $0.27 \mathrm{SD}$ in maths and $0.17 \mathrm{SD}$ in language. The group scheme increased scores by $0.22 \mathrm{SD}$ in maths and $0.09 \mathrm{SD}$ in language. Spillovers raised scores in non-incentive subjects too (from 0.11 to $0.18 \mathrm{SD}$ ).

Language test scores increase as a result of the decentralisation and increased community involvement

225,206 (structural equation) 546 (PSM)

$10 \%$ point average increase in the percentage of correct answers for Spanish, maths and science exams

While official autonomy as a status does not improve learning, when de facto autonomous practices are considered, an increase in maths test scores is recorded

Test score increased by $3.5 \%$ for maths and $5.4 \%$ in language, but the gains did not reach the poorest students

Management practices were improved only when the intervention was implemented at al decentralisation levels (that is, when school level implementation complemented distric and sub-district implementation), but the mpact on test scores was insignificant

\section{Source: Authors.}

${ }^{a}$ The study is recorded twice in order to separate the resource provision from the behavioural incentive component of the intervention. 


\section{References}

Anand, P., Mizala, A., Repetto, A., 2009. Using school scholarships to estimate the effects of private education on the academic achievement of low-income students in Chile. Econ. Educ. Rev. 28, 370-381.

Angrist, J., Bettinger, E., Bloom, E., King, E., Kremer, M., 2002. Vouchers for private schooling in Colombia: evidence from a randomized natural experiment. Am. Econ. Rev. 92 (5), 1535-1558.

Angrist, J., Bettinger, E., Kremer, M., 2006. Long-term educational consequences of secondary school vouchers: evidence from administrative records in Colombia. Am. Econ. Rev. 96 (3), 847-862.

Asadullah, M., 2005. The effect of class size on student achievement: evidence from Bangladesh. Appl. Econ. Lett. 12 (4), 217-221.

ASER, 2015. Annual Status of Education Report (Rural) 2014. ASER Centre, New Delhi.

Asiedu, E., Nandwa, B., 2007. On the impact of foreign aid in education on growth: how relevant is the heterogeneity of aid flows and the heterogeneity of aid recipients? Rev. World Econ. 143 (4), 631-649.

Baird, S., McIntosh, C., Ozler, B., 2011. Cash or condition? Evidence from a cash transfer experiment. Quart. J. Econ. 126 (4), 1709-1753.

Banerjee, A., Cole, S., Duflo, E., Linden, L., 2007. Remedying education: evidence from two randomized experiments in India. Quart. J. Econ. 122 (3), 1235-1264.

Barrera-Osorio, F., 2007. The impact of private provision of public education: empirical evidence from Bogotá's concession schoolsIn: WB Policy Research Working Papers No. 4121.

Barrera-Osorio, F., Linden, L., 2009. The use and misuse of computers in education: evidence from a randomized experiment in ColombiaIn: WB Policy Research Working Papers No. 4836.

Barro, R., 1991. Economic growth in a cross section of countries. Quart. J. Econ. CVI, 363-394.

Barro, R., Sala-i-Martin, X., 1998. Economic Growth. MIT Press, Cambridge, MA.

Barro, R.J., 2001. Human capital and growth. Am. Econ. Rev. 91 (2), 12-17.

Becker, G., Murphy, K., Tamura, R., 1990. Economic growth, human capital and population growth. J. Polit. Econ. 98 (5), S12-S137.

Becker, G.S., 1962. Investment in human capital: a theoretical analysis. J. Polit, Econ. 70 (5), 9-49.

Behrman, J.R., Parker, S.W., Todd, P.E., Wolpin, K.I., 2015. Aligning learning incentives of students and teachers: results from a social experiment in Mexican high schools. J. Polit. Econ. 123 (2), 325-364.

Benhabib, J., Spiegel, M.M., 1994. The role of human capital in economic development: evidence from aggregate cross-country data. J. Monetary Econ. XXVIII, 143-173.

Bjorkman, M., 2004. Public funding in the educational sector and its effect on test scores: evidence from UgandaIn: IIES Stockholm University Working Paper.

Burde, D., Linden, L., 2013. The effect of village-based schools: evidence from a randomized controlled trial in Afghanistan. Am. Econ. J. Appl. Econ. 5 (3), 27-40.

Conn, K., 2014. Identifying Effective Education Interventions in Sub-Saharan Africa: A Meta-analysis of Rigorous Impact Evaluations. Columbia University.

Contreras, D., 2001. Evaluating a voucher system in Chile. Individual, family and school characteristicsIn: Universidad de Chile and Yale University Working Paper Series.

Coombs, P.H., 1985. The World Crisis in Education: The View from the Eighties. Oxford University Press.

Das, J., Dercon, S., Habyarimana, J., Krishnan, P., 2004. When can school inputs improve test scores? In: CSAE Working Paper Series No. 25.

Dhaliwal, I., Duflo, E., Glennerster, R., Tulloch, C., 2012. Comparative costeffectiveness analysis to inform policy in developing countries: a general framework with applications for educationIn: Policy Action Lab Working Paper.

Di Gropello, E., Marshall, J., 2005. Teacher effort and schooling outcomes in rural Honduras. In: Vargas, E. (Ed.), Incentives to Improve Teaching. The World Bank, Washington, DC.

Duflo, E., Hanna, R., Ryan, S., 2012. Incentives work: getting teachers to come to school. Am. Econ. Rev. 102 (4), 1241-1278.

Duflo, E., Dupas, P., Kremer, M., 2015. School governance, teacher incentives, and pupil-teacher ratios: experimental evidence from Kenyan primary schools. J. Publ. Econ. 123, 92-110.

Evans, D., Kremer, M., Ngatia, M., 2009. The impact of distributing school uniforms on children's education in KenyaIn: Poverty Action Lab Working Paper No. 169.

Galiani, S., Gertler, P., Schargrodsky, E., 2008. School decentralization: helping the good get better, but leaving the poor behind. J. Publ. Econ. 92 (10-11), 2106-2120.

García Palomer, C., Paredes, R., 2010. Reducing the educational gap: good results in vulnerable groups. J. Dev. Stud. 46 (3), 535-555.

Glewwe, P., 2002. Schools and skills in developing countries: education policies and socioeconomic outcomes. J. Econ. Lit. 40 (2), 436-482.

Glewwe, P., Hanushek, E.A., Humpage, S., Ravina, R., 2014. School resources and educational outcomes in developing countries: a review of the literature from 1990 to 2010. In: Education Policy in Developing CountriesThe University of Chicago Press, Chicago.

Glewwe, P., Ilias, N., Kremer, M., 2010. Teacher incentives. Am. Econ. J. Appl. Econ. 2 (3), 205-227.
Glewwe, P., Kremer, M., 2006. Schools, teachers, and education outcomes in developing countries. In: Handbook of the Economics of EducationElsevier (Chapter 16)

Glewwe, P., Kremer, M., Moulin, S., 2009. Many children left behind? Textbooks and test scores in Kenya. Am. Econ. J. Appl. Econ. 1 (1), 112-135.

Glewwe, P., Kremer, M., Moulin, S., Zitzewitz, E., 2004. Retrospective vs. prospective analyses of school inputs: the case of flip charts in Kenya. J. Dev. Econ. 74 (1), 251-268.

Hanushek, E., Woessmann, L., 2012. Do better schools lead to more growth? Cognitive skills, economic outcomes, and causation. J. Econ. Growth 17 (4), 267-321.

Hanushek, E.A., Kimko, D.D., 2000. Schooling, labor-force quality, and the growth of nations. Am. Econ. Rev. 90 (5), 1184-1208.

Hanushek, E.A., Machin, S.J., Woessmann, L., 2010. Handbook of the Economics of Education. Elsevier Science.

Hanushek, E.A., Woessmann, L., 2008. The role of cognitive skills in economic development. J. Econ. Lit. 46 (3), 607-668.

He, F., Linden, L., MacLeod, M., 2008. How to teach English in India: testing the relative productivity of instruction methods within the Pratham English language education programIn: 3ie and PicTalk Working Paper.

He, F., Linden, L., MacLeod, M., 2009. A better way to teach children to read? Evidence from a randomised controlled trial. In: Poverty Action Lab Working Paper No. 154

Heckman, J.J., LaFontaine, P.A., 2010. The American high school graduation rate: trends and levels. Rev. Econ. Stat. 92 (2), 244-262.

Higgins, J.P.T., Green, S., 2008. Guide to the contents of a Cochrane protocol and review. In: Cochrane Handbook for Systematic Reviews of InterventionsJohn Wiley \& Sons, Ltd.

Hsieh, C., Urquiola, M., 2006. The effects of generalized school choice on achievement and stratification: evidence from Chile's voucher program. J. Publ. Econ. 90 (8-9), 1477-1503.

Jamison, E.A., Jamison, D.T., Hanushek, E.A., 2007. The effects of education quality on income growth and mortality decline. Econ. Educ. Rev. 26 (6), $771-788$

Jimenez, E., Sawada, Y., 1999. Do community-managed schools work? An evaluation of El Salvador's EDUCO program. World Bank Econ. Rev. 13 (3), 415-441.

Jones, S., 2016. How does classroom composition affect learning outcomes in Ugandan primary schools? Int. J. Educ. Dev. 48, 66-78.

King, E.M., Ozler, B., 2005. What's Decentralization Got To Do with Learning? School Autonomy and Student Performance. Kyoto University, Interfaces for Advanced Economic Analysis. DP 54, pp. 51-60.

Kingdon, G., Teal, F., 2007. Does performance related pay for teachers improve student performance? Some evidence from India. Econ. Educ. Rev. 473-486.

Kremer, M., 2003. Randomized evaluations of educational programs in developing countries: some lessons. Am. Econ. Rev. 93 (2), 102-106.

Kremer, M., Holla, A., 2009. Improving education in the developing world: what have we learned from randomized evaluations? Annu. Rev. Econ. 1, 513542.

Kremer, M., Miguel, E., Thornton, R., 2009. Incentives to learn. Rev. Econ. Stat. 91 (3), 437-456.

Krishnaratne, S., White, H., Carpenter, E., 2013. Quality education for all children? What works in education in developing countries. In: 3ie Working PaperInternational Initiative for Impact Evaluation (3ie), New Delhi.

Lassibille, G., Tan, J., Jesse, C., Van Nguyen, T., 2010. Managing for results in primary education in Madagascar: evaluating the impact of selected workflow interventions. World Bank Econ. Rev. 24 (2), 303-329.

Laurini, M.P., Andrade, de Carvalho E., 2012. New evidence on the role of cognitive skill in economic development. Econ. Lett. 117 (1), 123-126.

Linden, L., 2008. Complement or substitute? The effect of technology on student achievement in India. In: InfoDev Working Paper Series No. 17.

Lucas, R.E., 1988. On the mechanics of economic development. J. Monetary Econ. 22 (1), 3-42

Martínez Franzoni, J., Voorend, K., 2012. Blacks, Whites, or Grays? Conditional Transfers and Gender Equality in Latin America. Social Politics: International Studies in Gender, State \& Society.

McEwan, P.J., 2014. Improving learning in primary schools of developing countries: a meta-analysis of randomized experiments. Rev. Educ. Res.

Moher, D., Liberati, A., Tetzlaff, J., Altman, D.G., 2009. Preferred reporting items for systematic reviews and meta-analyses: the PRISMA statement. Br. Med. J. 339, 1-13.

Muralidharan, K., Sundararaman, V., 2010. The impact of diagnostic feedback to teachers on student learning: experimental evidence from India. Econ. J. 120 (546), 187-203.

Muralidharan, K., Sundararaman, V., 2011. Teacher performance pay: experimental evidence from India. J. Polit. Econ. 119 (1), 39-77.

Nguyen, T., 2008. Information, role models and perceived returns to education: experimental evidence from MadagascarIn: Poverty Action Lab Working Paper.

Niño-Zarazúa, M., 2011. Mexico’s Progresa-Oportunidades and the emergence of social assistance in Latin America. In: BWPI Working Paper No. 142. Brooks World Poverty Institute, Manchester.

Paqueo, V., Lopez-Acevedo, G., 2003. Supply-side school improvement and the learning achievement of the poorest children in indigenous and rural schools: the case of PAREIn: WB Policy Research Working Paper Series No. 3172. 
Petrakis, P.E., Stamatakis, D., 2002. Growth and educational levels: a comparative analysis. Econ. Educ. Rev. 21 (5), 513-521.

Petrosino, A., Morgan, C., Fronius, T., Tanner-Smith, E., Boruch, R., 2012. Interventions in developing nations for improving primary and secondary school enrollment of children: a systematic review. Campbell Syst. Rev. (October).

Psacharopoulos, G., 1981. Returns to education: an updated international comparison. Comp. Educ. 17 (3), 321-341.

Psacharopoulos, G., 1985. Returns to education: a further international update and implications. J. Hum. Resour. 20 (4), 583-604.

Psacharopoulos, G., Patrinos, H.A., 2004. Returns to investment in education: a further update. Educ. Econ. 12 (2), 111-134.

Psacharopoulos, G., Tan, J.P., Jiminez, E., 1986. Financing Education in Developing Countries: An Exploration of Policy Options. The World Bank, Washington, DC.

Rau, T., Contreras, D., 2009. Tournaments, gift exchanges, and the effect of monetary incentives for teachers: the case of ChileIn: Universidad de Chile Working Paper Series.

Rebelo, S., 1991. Long-run policy analysis and long-run growth. J. Polit. Econ. 99 (3), 500.

Reimers, F., 1993. Time and opportunity to learn in Pakistan's schools: some lessons on the links between research and policy. Comp. Educ. 29 (2), 201-212.
Riddell, A., Niño-Zarazúa, M., 2016. The Effectiveness of Foreign Aid to Education. What Can Be Learned? Int. J. Educ. Dev. 48, 23-36.

Romer, P.M., 1994. The origins of endogenous growth. J. Econ. Perspect. 8 (1), 3. Schultz, T.W., 1961. Investment in human capital. Am. Econ. Rev. 51 (1), 1-17. Sen, A., 1999. Development as Freedom. Oxford University Press, Oxford.

Suh, S., Suh, J., 2007. Risk factors and levels of risk for high school dropouts. Prof. School Couns. 10 (3), 297-306.

Tilak, J.G., 1988. 'Foreign aid for education. Int. Rev. Educ. 34 (3), 313-335.

UNESCO, 2007. EFA Global Monitoring Report 2008 Education for All by

2015 Will We Make it? United Nations Education, Science and Cultural Organization, Paris.

UNESCO, 2011. Education Counts: Towards the Millennium Development Goals. http://unesdoc.unesco.org/images/0019/001902/190214e.pdf (accessed 18.11.13).

UNESCO, 2014. 'Teaching and Learning: Achieving quality for all'. Education for All Global Monitoring Report. UNESCO, Paris.

Vermeersch, C., Kremer, M., 2005. School meals, educational achievement and school competition: evidence from a randomized evaluationIn: WB Policy Research Working Paper Series, ISSN 1813-9450.

World Bank, 1980. World Development Report. Oxford University Press, New York 